\title{
ON THE THERMAL REgIME OF A HIGH-ARGTIC VAlLEY GLACIER
}

\author{
By Fritz MüLleR \\ (Eidg. Technische Hochschule, Zürich, Switzerland, and McGill University, Montreal, \\ Quebec, Canada)
}

\begin{abstract}
The $10 \mathrm{~m}$ temperatures were measured over several years at 16 sites on the White Glacier (lat. $80^{\circ}$ N.), Axel Heiberg Island, Canadian Arctic Archipelago. At three sites deep profiles were made using a new drilling technique, reaching a maximum depth of $280 \mathrm{~m}$. Large differences in the $10 \mathrm{~m}$ temperatures between locations and from year to year were observed. The deviations of these temperatures from the almost isothermal mean annual air temperature over the glacier are discussed. The heating effect of the melt water in the lower percolation zone was found to be very important. A conceptual model is developed to assess the influence of these irregularities in the energy input at the upper boundary on the thermal regime of the entire glacier. So far a quantitative analysis has been made only for the relatively simple $30 \mathrm{~m}$ temperature profile measured on the tongue of the glacier.

RÉsumé Le régime thermique d'un glacier de vallée dans l'Arctique. La répartition des températures à $10 \mathrm{~m}$ de profondeur a été mesurée pendant plusieurs années en 16 endroits du White Glacier (lat. $80^{\circ} \mathrm{N}$.) à Axel Heiberg Island, dans l'archipel arctique canadien. En trois différents endroits des forages profonds furent effectués en appliquant une technique de forage nouvelle, atteignant une profondeur de $280 \mathrm{~m}$. De grandes différences ont été observées dans les températures à $10 \mathrm{~m}$ de profondeur en fonction de leur emplacement et de l'année d'observation. Les écarts entre ces températures et la température annuelle moyenne presque isotherme de l'air au-dessus du glacier sont analysées. Il s'est révélé que l'effet calorifère de l'eau de fonte dans la zone inférieure de percolation est très important. Un modèle conceptuel est developpé dans le but d'évaluer l'influence de ces irrégularités dans le flux d'énergie à sa limite supérieure sur le régime thermique du glacier tout entier. Jusqu'à présent une analyse quantitative n'a été effectué que pour le profil thermique relativement simple de $30 \mathrm{~m}$ de profondeur mesuré dans la langue du glacier.

Zusammenfassung. Zum Wärmehaushalt eines hocharktischen Talgletschers. Während mehrerer Jahre wurden an 16 Stellen auf dem White Glacier $\left(80^{\circ}\right.$ N.) auf der Axel Heiberg Island im kanadischen arktischen Archipel, die oberflächennahmen Temperaturen, insbesondere jene in $10 \mathrm{~m}$ Tiefe, gemessen. An drei Messstellen wurden mit Hilfe einer neuen Bohrtechnik Temperaturprofile bis zu einer Tiefe von $280 \mathrm{~m}$ erstellt. Bei den Io $\mathrm{m}$ Temperaturen wurden grosse Unterschiede festgestellt sowohl von Ort zu Ort wie auch von Jahr zu Jahr. Die Abweichungen dieser Temperaturen von der beinah isothermen mittleren jährlichen Lufttemperatur über dem Gletscher werden diskutiert. Dabei wurde der Aufwärmeeffekt des versickerten Schmelzwassers der "unteren Perkolationszone" als sehr wichtig erkannt. Es wurde ein Modell entwickelt, um den Einfluss der unregelmässigen Energiezufuhr an der Gletscheroberfläche auf den Wärmehaushalt des ganzen Gletschers abzuschätzen. Eine quantitative Analyse ist vorläufig erst für das relativ einfache, nur bis zu einer Tiefe von $30 \mathrm{~m}$ gemessene Temperaturprofil auf der Gletscherzunge ausgeführt worden.
\end{abstract}

\section{INTRODUCTION}

The thermal regime of the White Glacier (Fig. I), a medium-sized valley glacier on Axel Heiberg Island, lat. $80^{\circ}$ N., in the Canadian Arctic Archipelago, has been studied since r959 as part of a continuous and still ongoing glaciological programme organized by McGill University. This simple-shaped glacier of $16 \mathrm{~km}$ length with a smooth longitudinal profile descending from an elevation of $\mathrm{r} 800 \mathrm{~m}$ to $60 \mathrm{~m}$ above sea-level may be typical for many Arctic glaciers.

Some early results from this study pertaining mainly to the seasonal temperature variations within the first $10 \mathrm{~m}$ below the glacier surface in the accumulation and ablation areas and the zone of superimposed ice near the equilibrium line already indicated a much more complicated thermal regime than anticipated for the White Glacier (Müller, I96i, I963[a], [b]). Still too often the assumption is made that the roughly sinusoidal seasonal changes of the air temperature would penetrate the top layers of a glacier to a depth of some $10 \mathrm{~m}$, and that the temperature read at this depth could be equated with the mean annual air temperature. In the case of the White Glacier no such agreement was found. The present paper presents further detail of these "anomalies". Similarly "anomalous" temperatures within and below the seasonally changing layers of Arctic glaciers have been reported from 
north-western Greenland (Schytt, I955; Benson, 1962), Spitsbergen (Schytt, 1964, 1969), Zemlya Frantsa-Iosifa (Krenke, I963), Novaya Zemlya (Khmelevskoy, I968), Alaska (Miller, [1956]; Orvig and Mason, I963; Trabant and others, 1975).

Following on the preliminary findings it was decided to extend the study of the thermal regime of the White Glacier to include a detailed assessment of the temperature variations over many years for as many parts of the glacier as possible and finally to add measurements of temperatures throughout its depth. The White Glacier is particularly suitable for such a detailed investigation as much information - up to 15 years of data - is available on other aspects governing the behaviour of this glacier: geometry, in part based on seismic data (Redpath, 1965); surface velocities and their fluctuations and the associated hydrologic regime (Maag, I969; Müller and Iken, I973; Iken, I974); accumulation and ablation patterns (Müller, I962; Adams, I966); and micrometeorological and climatic data including records from three automatic weather stations.

\section{INSTRUMENTATION AND OBSERVATION SITES}

The temperatures were recorded with strings of thermistors frozen into the ice and read with a Wheatstone bridge (Tettex type). Platinum resistance elements were used for independent checking at selected points. The thermistors were calibrated to an accuracy of \pm . I deg and better; taking into account the instrument error of the bridge an absolute accuracy of $\pm 0.2 \mathrm{deg}$ for all measured values can be claimed. Recalibration of the retrieved thermistors and comparison of the data with those obtained from the more stable platinum resistance elements (operating accuracy better than $\pm 0 . \mathrm{I} \mathrm{deg}$ ) showed that no significant shift of the calibration values had taken place during the many years of field use. Though the temperature-measuring devices were individually connected to the surface and placed in specially designed casings to protect them against high pressure resulting from the freezing-in process and the differential movement of the ice masses over the years, none of them remained functional for longer than eight years.

The shallow holes were hand-drilled using a 3 inch $(7.6 \mathrm{~cm})$ Teflon-coated SIPRE coring auger. The three deep holes (to a maximum depth of $280 \mathrm{~m}$ ) were drilled during the summer of I974 with a most efficient new type of open system, hot-water drill, adapted from a design by Kasser, Röthlisberger and Iken. In this equipment, the water (local surface melt water), heated by two propane burners and pumped with a pressure of some 20 atmospheres through a rubber tube insulated with PVC, is released through a $4 \mathrm{~mm}$ jet at the end of the $2 \mathrm{~m}$ long drill head, which is stabilized with about $3 \mathrm{~kg}$ of lead grains. An advance rate of $25 \mathrm{~m}$ to $50 \mathrm{~m}$ per hour was achieved with the drill in the cold ice of the White Glacier.

The distribution of the temperature measurement sites on and in front of the White Glacier is shown in Figure $\mathrm{I}$. So far only one site-Beaver Camp - is permanently located in the accumulation area. Most sites are near or just below the mean equilibrium line. The annual equilibrium line changes its position widely from year to year; in 1962 it was found at an elevation of $1300 \mathrm{~m}$ while in 1964 it fell to only $400 \mathrm{~m}$ above sea level. The three temperature measurement sites in the Anniversary profile and the cluster of sites on the tongue are clearly in the ablation area.

\section{The data}

The main purpose of the present study was to assess differences in temperatures at the Io $\mathrm{m}$ depth over the entire White Glacier and to check if the findings varied over the years. To permit comparison between the different parts of the glacier and over many years it was necessary to take the temperature readings more or less simultaneously and always at the 


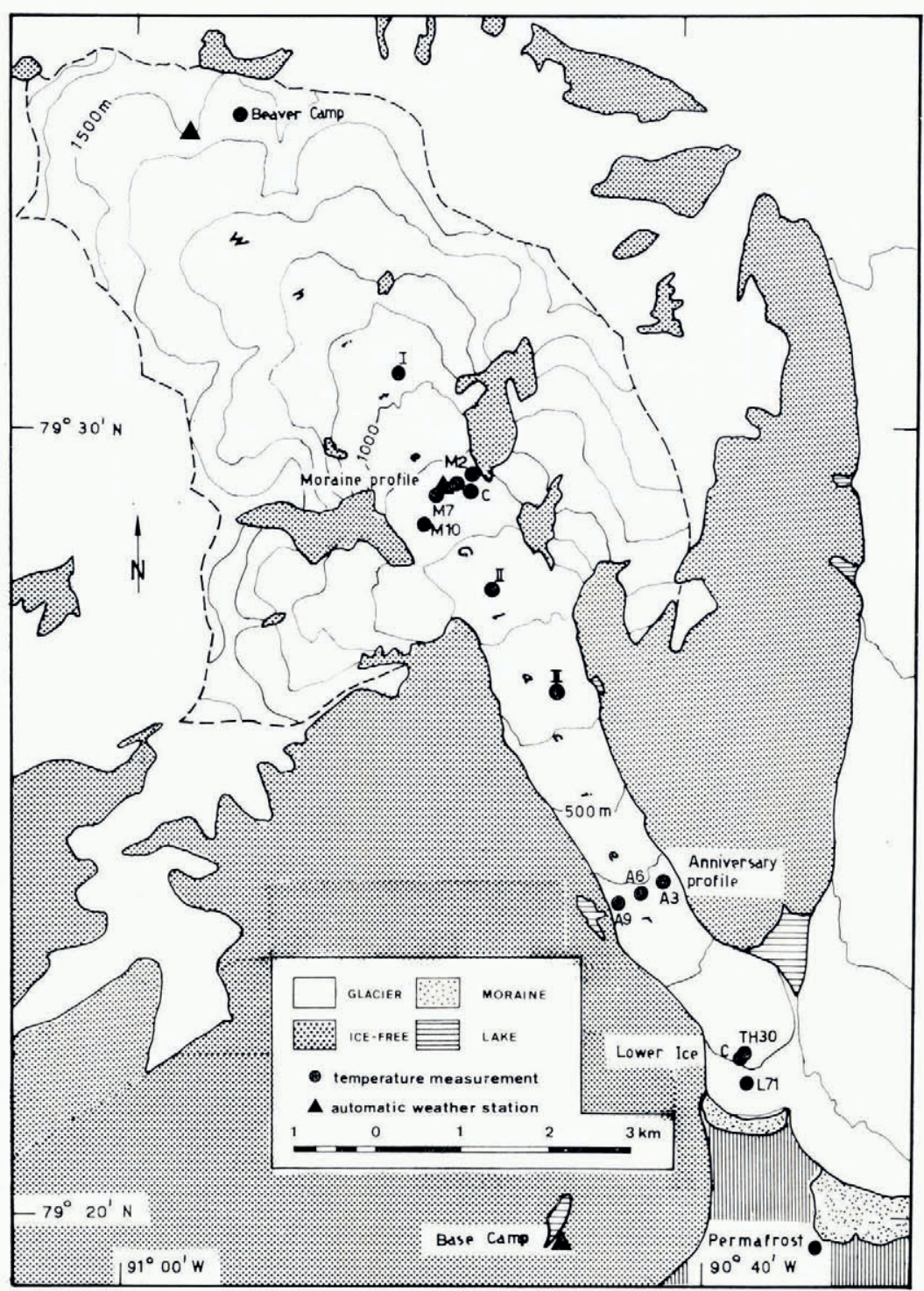

Fig. 1 . Location map, showing all englacial temperature measurement sites on the White Glacier to date and their names and symbols. The positions of the three automatic weather stations on and near the glacier and the site of a temperature profile in the permafrost in front of the glacier are also indicated.

same time of the year, e.g. at the end of the accumulation season in late August. Furthermore, the shift of the zero level of the profile due to accumulation and ablation had to be taken into account when plotting the data for these comparisons. Figures 2, 3, 4 and 5 present the nearsurface temperature comparison over a number of years from the highest to the lowest site on the glacier. The differences from year to year are largest at Beaver Camp (accumulation area), are already considerably less at Moraine Camp (site G) and are small at the two ablation area sites, Anniversary profile and Lower Ice. 


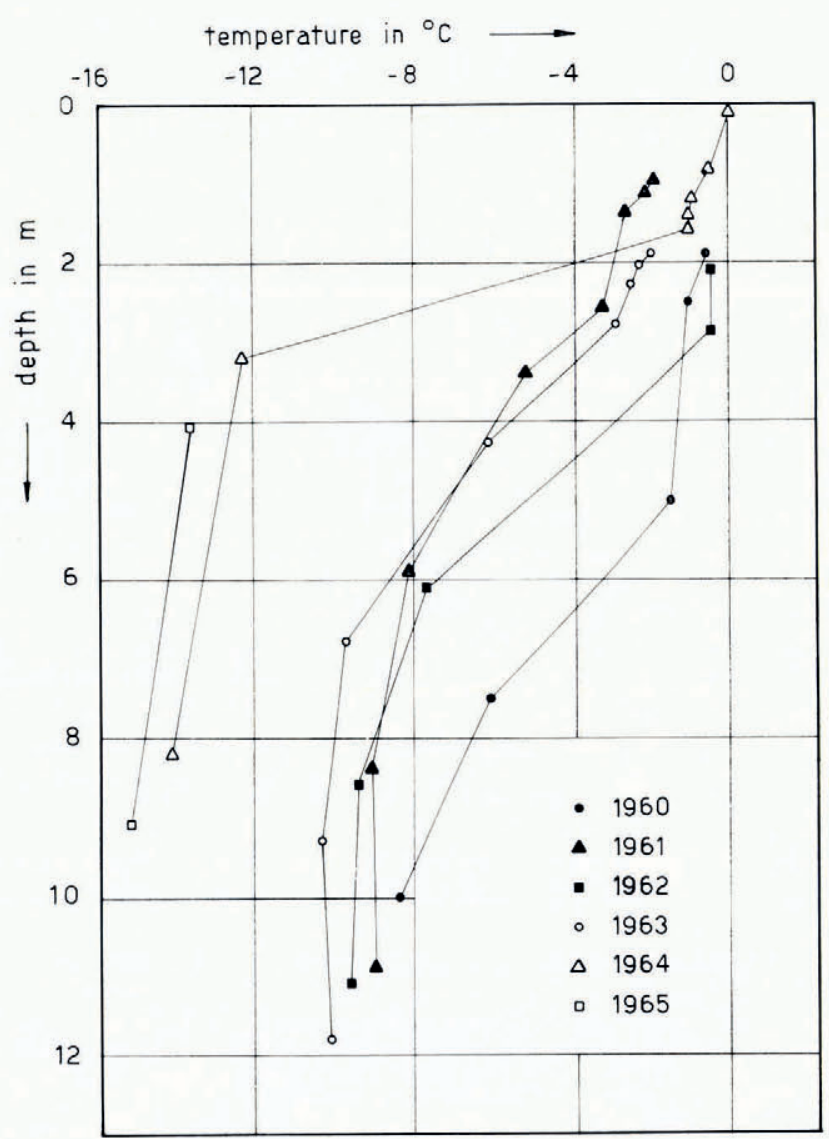

Fig. 2. Late-summer near-surface temperatures at Beaver Camp I $424 \mathrm{~m}$.

Figure 4 also shows the comparison of shallow-depth temperatures from sites on the eastern (A3), central (A6) and western (A9) portion of the Anniversary cross-profile. The ice near the centre line of the glacier is coldest, while the ice along the steep basaltic rock wall on the east side is almost 4 deg warmer. Equally large temperature differences were observed across the Moraine profile (Table I), with the coldest ice being found near the eastern margin of the glacier ( $\mathrm{M}_{2}$ and $\left.\mathrm{M}_{4}\right)$ and the warmest on the western side (Mro); in August r963 the difference amounted to $4.5 \mathrm{deg}$. During the budget year $1962 / 63$ - as during many othersthe western portion of the "Moraine" profile remained firn covered, resulting from a relatively thick winter snow pack and little ablation during the summer, whereas in the eastern half of the profile bare ice was already exposed in spring and possibly during much of the winter. Both firn line and slush limit are usually situated higher on the eastern side of the glacier than on the western parts.

During the summer 1974 additional shallow-depth temperatures were obtained from three deep-drilling sites: Site I at a short distance above the mean equilibrium line, and sites II and III respectively $2 \mathrm{~km}$ and $4 \mathrm{~km}$ below it (Fig. I). The data collected from these sites (Fig. 6 and Table I) in no way simplified the pattern of temperature distribution at the Io $\mathrm{m}$ depth. Site II, expected to show low temperatures, proved to contain warmer ice than either of the other two (this situation existed not only near the surface but extended to a depth 
of some $\mathrm{I} 6 \mathrm{o} \mathrm{m})$. Sites I-III were thought to be close enough to a central flow line to provide information on the longitudinal development of the temperature pattern. It now seems that the slight deviation of site II to the west brought it into the realm of the warmer ice descending on the western side of the "Moraine" profile, while the displacement of site III by an amount of $200 \mathrm{~m}$ to the east of the centre line put its profile into the stream of colder ice coming from the $\mathrm{M}_{4}$ area. The surrounding of site II frequently forms an accumulation outlier, whereas site III lies in an area of strong ablation and reduced winter snow due to wind abrasion.

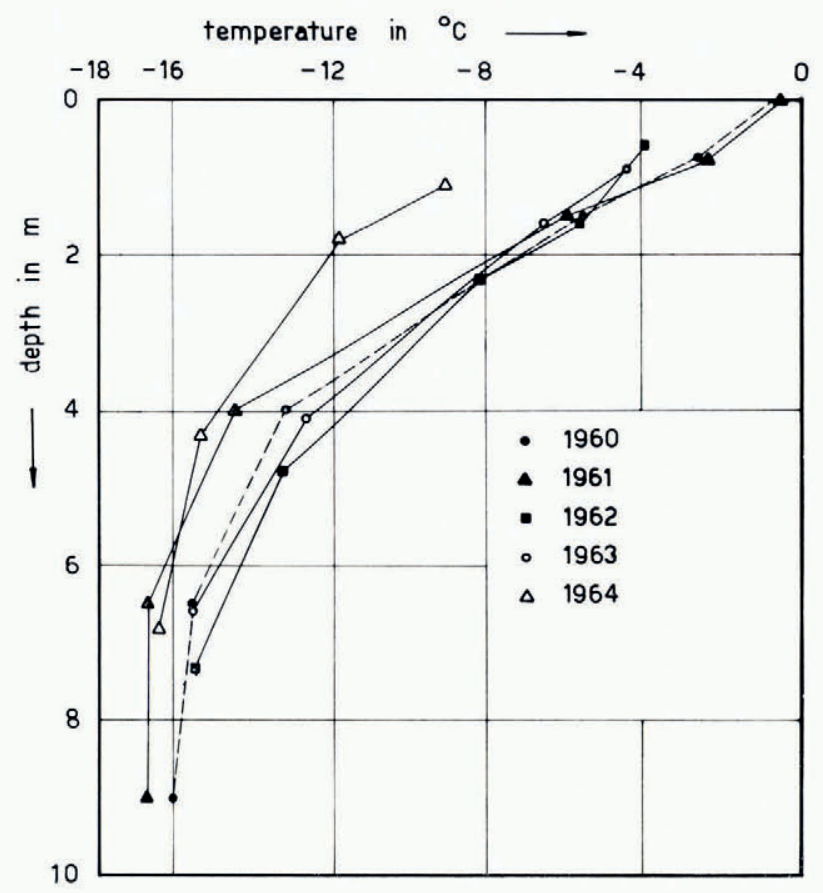

Fig. 3. Late-summer near-surface temperatures at Moraine Camp C $852 \mathrm{~m}$.

To summarize all the $10 \mathrm{~m}$ depth temperature data (including one value from a site in the permafrost area in front of the glacier), all values are plotted against altitude and put in juxtaposition with the mean annual air temperature over the White Glacier area in Figure 7. The air-temperature profile was calculated from the $195^{\mathrm{I}-60}$ surface and aerological (950 and 850 mbar level) records of the weather stations at Eureka and Isachsen used in conjunction with the data collected by the three automatic weather stations on Axel Heiberg Island at the Base Camp, on the glacier near the Moraine profile and near Beaver Camp. A statistical relationship of the form $T=a+b T_{\text {in }}$ was applied, where $T$ is the temperature over the glacier surface computed from the large-scale atmospheric temperatures $T_{\text {in }}$ obtained by interpolation between Eureka and Isachsen records. Thirty months of automatic weather-station data from the White Glacier area was available for this calculation. A strong mean annual inversion to an elevation of about $200 \mathrm{~m}$ and from there an almost isothermal air temperature profile over the glacier to an elevation of at least $\mathrm{I} 500 \mathrm{~m}$ was found. 


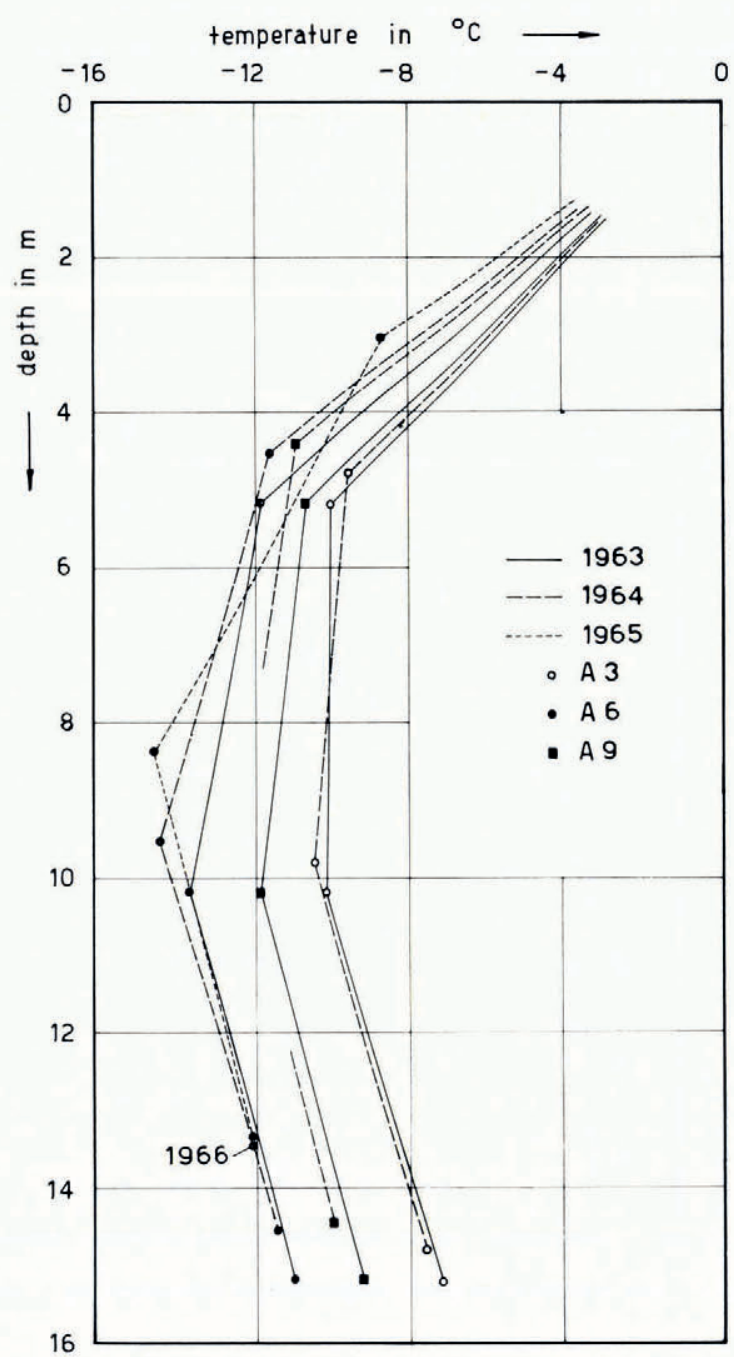

Fig. 4. Comparison of late-summer near-surface temperatures across the glacier at Anniversary profile $370 \mathrm{~m}$.

\section{Discussion of Results}

\section{I. The ro $m$ temperatures as upper boundary input}

Figure 7 clearly shows that there is no simple relationship between the mean annual air temperature and the near-surface, i.e. the ro $\mathrm{m}$, temperature of the White Glacier. The magnitude of difference between the two quantities is given by the horizontal distance between the ro $\mathrm{m}$ temperature points and the air temperature curve on the left-hand side of the figure. Deviations of up to ro deg are found. The large spread of these deviations - though made more obvious by plotting both regional and time variations on one graph-indicates a complexity of causes. Attempts to connect related $10 \mathrm{~m}$ temperature points did not yield satisfactory results. Instead two strongly different situations are shown schematically. The solid line starts with the Beaver Camp site being part of the lower percolation zone, while the 


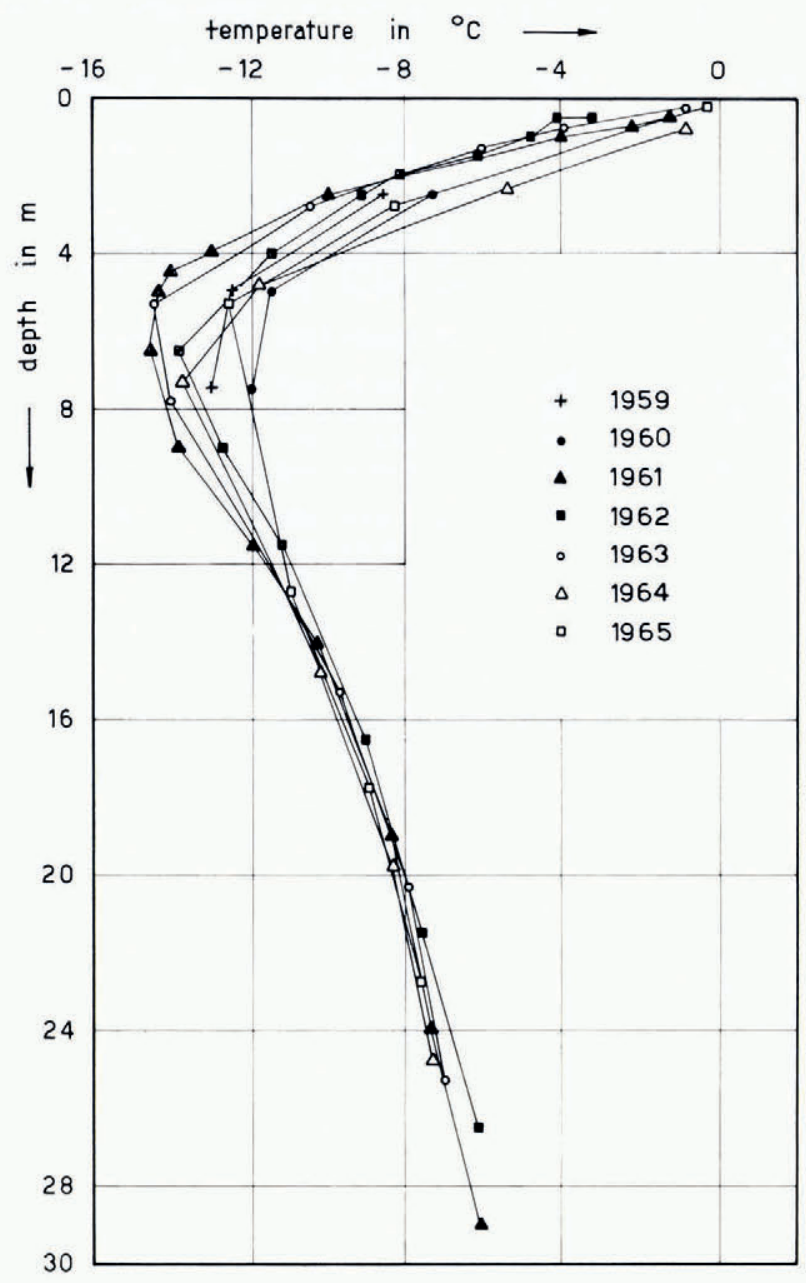

Fig. 5. Late-summer near-surface temperatures at Lower Ice $205 \mathrm{~m}$.

dashed line commences at a Beaver Camp which belongs to the upper percolation zone. The solid line thus depicts a situation in which the equilibrium line on the White Glacier would be situated for some years at an elevation of 800 to $\mathrm{I}$ ooo $\mathrm{m}$ a.s.1. The dashed line shows the thermal "surface" situation of a White Glacier with the equilibrium line for a number of years at an elevation of $400 \mathrm{~m}$ to $600 \mathrm{~m}$ a.s.l., i.e. as it existed in 1964 and 1965 .

The above interpretation of the data is elucidated by Figure 8 which shows qualitatively and schematically the thermal influence of the different accumulation zones. A description of the characteristics of the various zones is given in Müller (1962). The input of energy into the glacier through percolating melt water and the release of latent heat during refreezing at depth is strongest in the lower percolation zone. On the White Glacier this process has been found to be active to a depth of up to $6 \mathrm{~m}$ below the surface, which can represent as much as eight years of accumulation. In one case, in $1966,25 \mathrm{~cm}$ of wet firn were found at a depth of $7.2 \mathrm{~m}$ below almost $3 \mathrm{~m}$ of solid ice in a hole made in the lower percolation zone with a 
Table I. 10 m temperatures in the White Glacier, Axel Heiberg Island, N.W.T.

\begin{tabular}{|c|c|c|c|c|}
\hline Location & $\begin{array}{l}\text { Elevation } \\
\mathrm{m} \text { a.s.l. }\end{array}$ & $\begin{array}{c}\text { Date of } \\
\text { observation }\end{array}$ & $\begin{array}{l}\text { Temperature at } \\
\text { Io m depth } \\
{ }^{\circ} \mathrm{C}\end{array}$ & $\begin{array}{l}\text { Estimated } \\
\text { accuracy } \\
\text { deg }\end{array}$ \\
\hline Beaver Camp & I 424 & 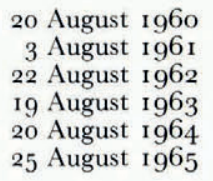 & $\begin{array}{r}-8.4 \\
-9.1 \\
-9.6 \\
-10.3 \\
-14.1 \\
-15.2\end{array}$ & $\begin{array}{l} \pm 0.5 \\
\pm 0.5 \\
\pm 0.5 \\
\pm 0.5 \\
\pm 0.7 \\
\pm 0.7\end{array}$ \\
\hline Deep drill, site I & 1024 & ${ }_{25}$ August 1974 & -12.3 & \pm 0.5 \\
\hline $\begin{aligned} \text { Moraine profile } & \mathrm{M}_{2} \\
& \mathrm{M}_{4} \\
& \mathrm{M}_{7} \\
& \mathrm{M}_{\mathrm{I0}}\end{aligned}$ & $\begin{array}{l}863 \\
866 \\
879 \\
860\end{array}$ & $\begin{array}{l}\text { 19 August 1963 } \\
\text { 19 August I963 } \\
\text { 19 August I963 } \\
\text { 19 August I } 963\end{array}$ & $\begin{array}{l}-16.0 \\
-17.0 \\
-13.1 \\
-12.5\end{array}$ & $\begin{array}{l} \pm 1.0 \\
\pm 0.7 \\
\pm 0.5 \\
\pm 0.7\end{array}$ \\
\hline Moraine profile, site $\mathrm{C}$ & 844 & $\begin{array}{l}19 \text { August } 1960 \\
3 \text { August } 1961 \\
22 \text { August } 1962 \\
19 \text { August } 1963 \\
20 \text { August } 1964\end{array}$ & $\begin{array}{l}-16.0 \\
-16.6 \\
-15.5 \\
-15.7 \\
-16.3\end{array}$ & $\begin{array}{l} \pm 0.5 \\
\pm 0.5 \\
\pm 0.5 \\
\pm 0.7 \\
\pm 0.7\end{array}$ \\
\hline Deep drill, site II & 717 & 25 August 1974 & -11.4 & \pm 0.5 \\
\hline Deep drill, site III & 626 & 25 August 1974 & -14.8 & \pm 0.5 \\
\hline $\begin{array}{r}\text { Anniversary profile } \mathrm{A}_{3} \\
\mathrm{~A}_{3}\end{array}$ & $3^{8} \mathbf{I}$ & $\begin{array}{l}25 \text { August I } 963 \\
22 \text { August I } 964\end{array}$ & $\begin{array}{l}-10.2 \\
-10.3\end{array}$ & $\begin{array}{l} \pm 0.5 \\
\pm 0.5\end{array}$ \\
\hline $\begin{array}{ll}\mathrm{A}_{6} \\
\mathrm{~A}_{6} \\
\mathrm{~A}_{6}\end{array}$ & $\begin{array}{l}389 \\
388\end{array}$ & $\begin{array}{l}25 \text { August } 1963 \\
22 \text { August } 1964 \\
25 \text { August } 1965\end{array}$ & $\begin{array}{l}-13.7 \\
-14.2 \\
-13.9\end{array}$ & $\begin{array}{l} \pm 0.5 \\
\pm 0.5 \\
\pm 0.5\end{array}$ \\
\hline $\begin{array}{l}\mathrm{A}_{9} \\
\mathrm{~A}_{9}\end{array}$ & $35^{2}$ & $\begin{array}{l}25 \text { August } 1963 \\
22 \text { August } 1964\end{array}$ & $\begin{array}{l}-11.9 \\
-12.2\end{array}$ & $\begin{array}{l} \pm 0.5 \\
\pm 0.7\end{array}$ \\
\hline $\begin{array}{r}\text { Lower Ice, site C } \\
\text { site C }\end{array}$ & 209 & $\begin{array}{l}\text { 19 August } 1959 \\
\text { 19 August } 1960\end{array}$ & $\begin{array}{l}-12.3 \\
-11.7\end{array}$ & $\begin{array}{l} \pm 0.5 \\
\pm 0.7\end{array}$ \\
\hline site $\mathrm{TH}_{30}$ & $\begin{array}{l}206 \\
205\end{array}$ & $\begin{array}{l}18 \text { August } 1961 \\
26 \text { August } 1962 \\
2 \text { August } 1963 \\
22 \text { August } 1964 \\
25 \text { August } 1965\end{array}$ & $\begin{array}{l}-13.0 \\
-12.1 \\
-12.7 \\
-12.4 \\
-11.8\end{array}$ & $\begin{array}{l} \pm 0.5 \\
\pm 0.5 \\
\pm 0.5 \\
\pm 0.5 \\
\pm 0.5\end{array}$ \\
\hline $\mathrm{L}_{7 \mathrm{I}}$ & 164 & $\begin{array}{l}25 \text { August r } 963 \\
22 \text { August r } 964\end{array}$ & $\begin{array}{l}-11.4 \\
-11.9\end{array}$ & $\begin{array}{l} \pm 0.5 \\
\pm 0.5\end{array}$ \\
\hline Permafrost site & 26 & $\begin{array}{l}\text { late July 1968 } \\
\text { I4 August } 1969\end{array}$ & $\begin{array}{l}-13.6 \\
-14.5\end{array}$ & $\begin{array}{l} \pm \mathrm{r} .0 \\
\pm 0.5\end{array}$ \\
\hline
\end{tabular}

SIPRE coring auger. The amount of heat input by the percolation process decreases drastically in the slush zone. In the superimposed ice zone and the zone of transitional superimposed ice, situated immediately below the equilibrium line, some heat is provided to the glacier by the refreezing process. Only in the dry snow zone and the lower parts of the ablation area does the heat input through glaciological process become negligible.

If as a result of climatic changes the different accumulation zones are shifted to higher or lower elevations, the resulting effect for a given area on the glacier can be contrary to what would be expected. Figure 8 demonstrates that in the case of a negative climatic change the slush zone may become a lower percolation zone and thus receive more energy input, while a positive climatic change may provide less heat to the area of the original lower percolation zone. 


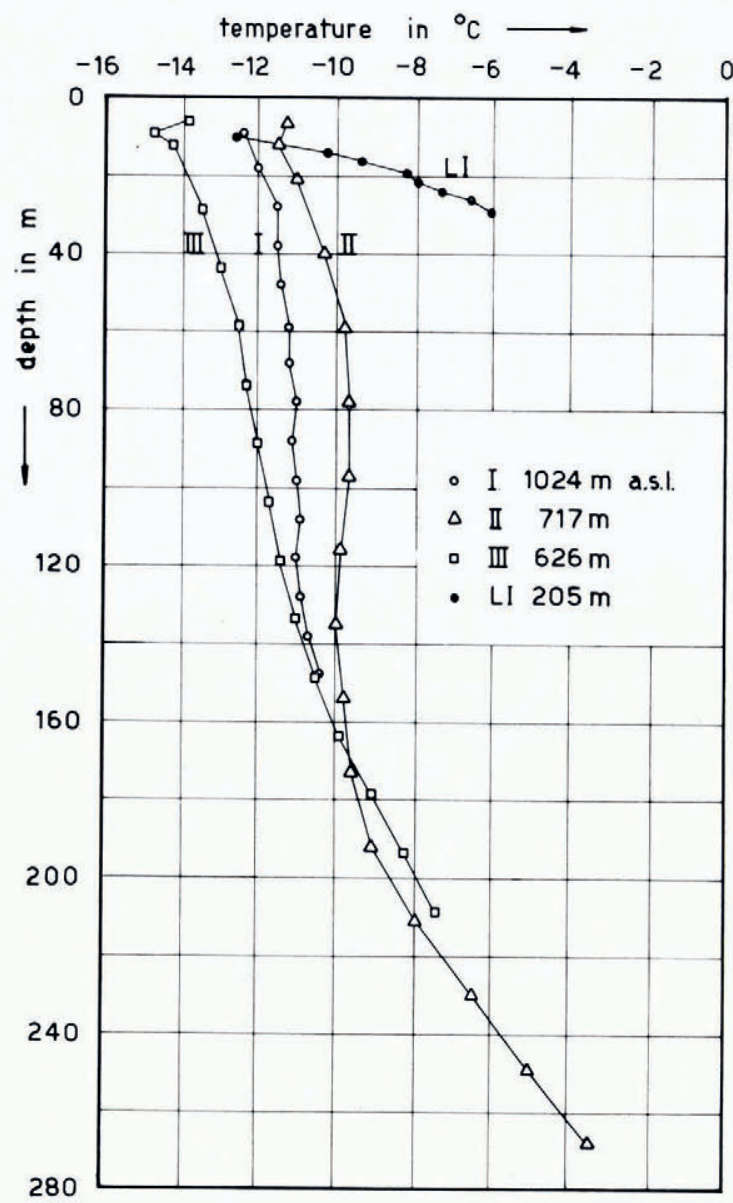

Fig. 6. Englacial temperatures, White Glacier, 25 August 1974.

\subsection{Influences on the Io $m$ temperature pattern}

The influence of the differential energy input at the surface on the thermal regime of the glacier is qualitatively depicted in Figure 9. The large irregularity in the near-surface isotherms in the accumulation area is dissipated downwards through conduction and is buried to even greater depth by the downward component of the ice movement, while at the same time being advanced towards the glacier terminus. In the ablation area the upward component of the ice movement shifts the isotherms towards the glacier surface.

A more realistic picture of the temperature distribution in the White Glacier is drawn in Figure I0. Irregularities in the frictional and geothermal heating are not considered in this presentation; the emphasis is placed on the distribution of the near-surface temperatures. As borne out by observation, the coldest temperatures are shown near the mean equilibrium line, while the warmest are to be found near the lower end of the lower percolation zone. Consequently it is suggested that the large heating in this area may result in the onset of basal sliding at approximately this point or somewhat down-glacier of it. 


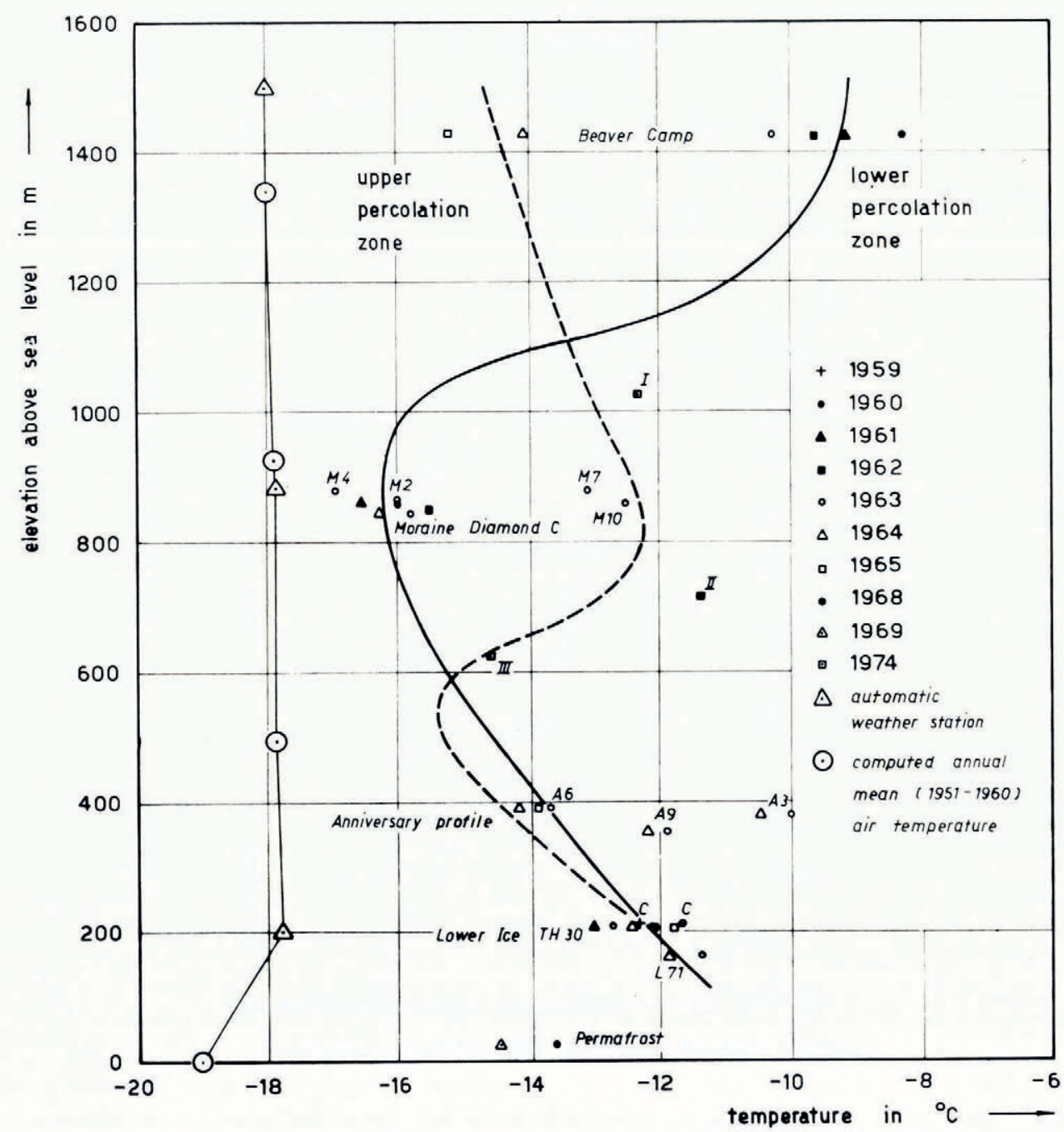

Fig. 7. Io $m$ depth temperatures, White Glacier. The left-hand line depicts the mean annual air temperatures; the solid curve approximates the upper boundary temperature condition for a White Glacier with a mean equilibrium line situated at an elevation of about $900 \mathrm{~m}$ a.s.l.; the dashed curve represents the glacier temperature situation associated with an equilibrium line elevation of about $500 \mathrm{~m}$ a.s.l. (N.B. These lines do not attempt to approximate the array of measured temperature points.)

\subsection{Deep temperatures and position of the pressure melting point}

None of the deep temperature profiles obtained in the White Glacier so far have reached bedrock. However, the lower portions of these profiles (Fig. 6) provide sufficient evidence to support the above-made suggestion that the White Glacier is able to slide over large portions of its bed. Extension of the almost linear lower parts of the profiles from sites II, III and LI meet the pressure melting point temperature at or above the approximately known glacier depth. At site II where the deepest thermistor at $268 \mathrm{~m}$ showed a temperature of $-3 \cdot 5^{\circ} \mathrm{C}$ the extrapolated profile reaches the pressure melting point of $-0.2^{\circ} \mathrm{C}$ between $300 \mathrm{~m}$ and 


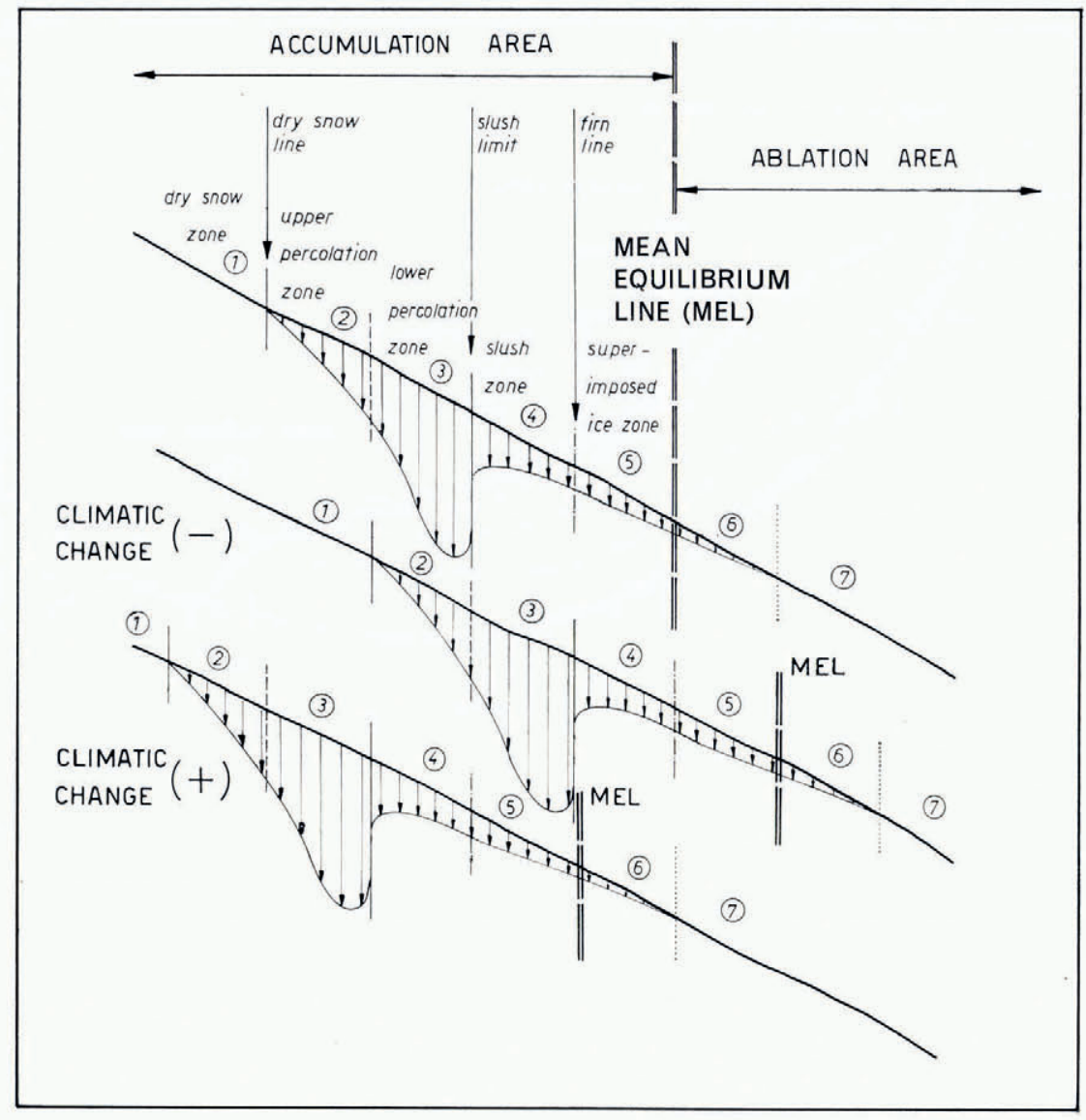

Fig. 8. Schematic presentation of thermal influence of the different accumulation zones $(6:$ zone of transitional superimposed ice; 7: ablation zone s.st.).
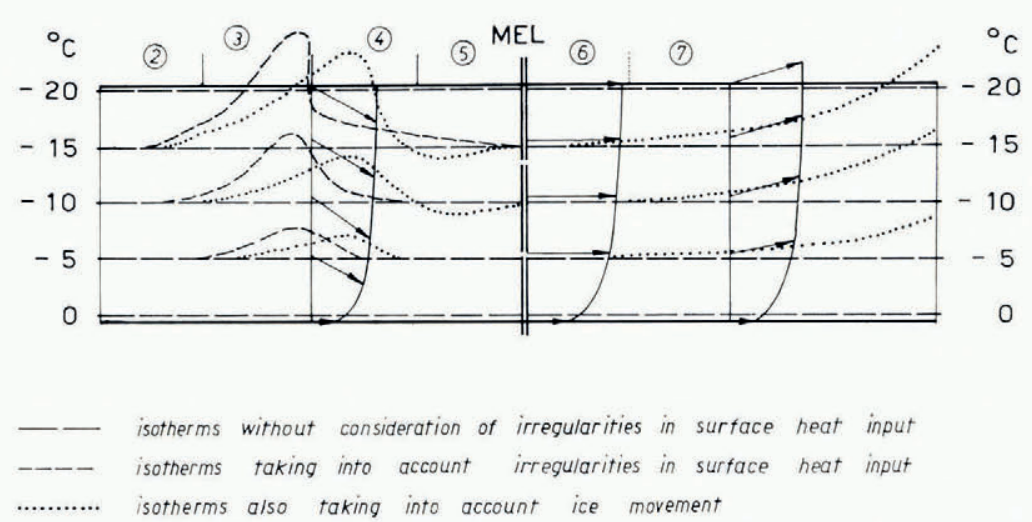

Fig. 9. Conceptual model showing thermal influence of the different accumulation and ablation zones (2-7) on a valley glacier, with and without glacier movement. 


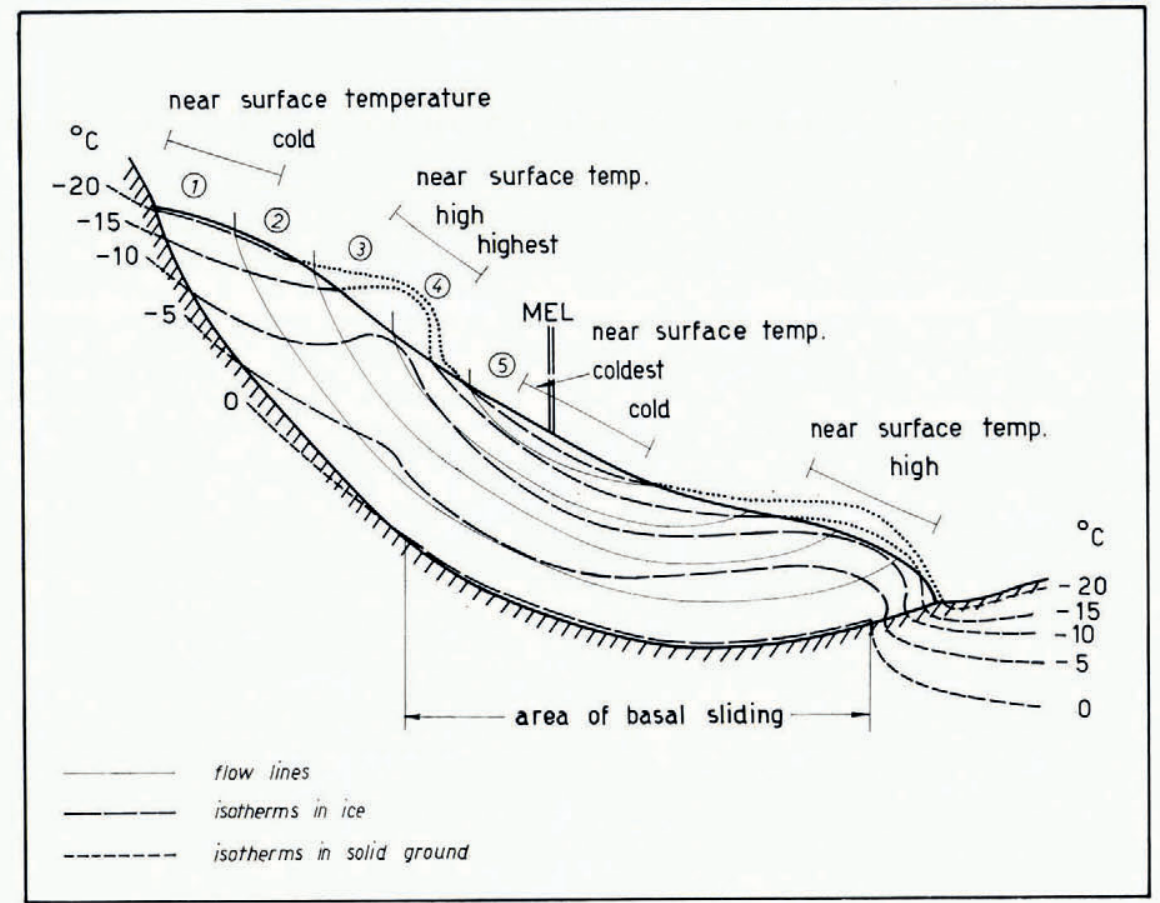

Fig. 10. Qualitative pattern of temperature distribution in an Arctic valley glacier ( $1-5:$ accumulation zones).

3 IO $\mathrm{m}$ depth. At site III, where the glacier may be slightly thicker, the profile also points to a somewhat lower position of the pressure melting point. The temperature gradient in the lowermost part of these profiles amounting to about $-0.08 \mathrm{deg} / \mathrm{m}$ is considerably larger than the geothermal heat flux would indicate.

\subsection{Outlook}

During the summers of 1975 and 1976 further deep drillings in the ablation and accumulation areas will be made. From the temperature profiles a quantitative analysis will then be attempted. So far a one-dimensional, homogeneous steady-state analysis of the temperatures measured in the $30 \mathrm{~m}$ "Lower Ice" profile was made, assuming two different glacier depths ( $120 \mathrm{~m}$ and $\mathrm{I} 30 \mathrm{~m}$ ), a surface-normal movement component of $2 \mathrm{~m} /$ year and temperature gradients of $-0.033 \mathrm{deg} / \mathrm{m}$ and $-0.025 \mathrm{deg} / \mathrm{m}$ respectively at the bottom of the glacier. Both solutions produced a good fit with the observed data (Fig. I I). The analysis of the deep profiles (sites I, II, III and other) will require a more complex approach.

\section{Acknowledgements}

The author is most indebted to many members of the Axel Heiberg Island Expedition for helpful assistance in the field and in the office. Heinz Blatter carried out the laborious task of deep drilling at sites I, II , and III. Roger Braithwaite calculated the mean annual air temperature profile shown on Figure 7. Atsumu Ohmura provided many valuable contributions to the discussion. Logistic support was generously made available by the Polar Continental Shelf Project of the Canadian Department of Energy, Mines and Resources. The project received financial support from the National Research Council of Canada. 


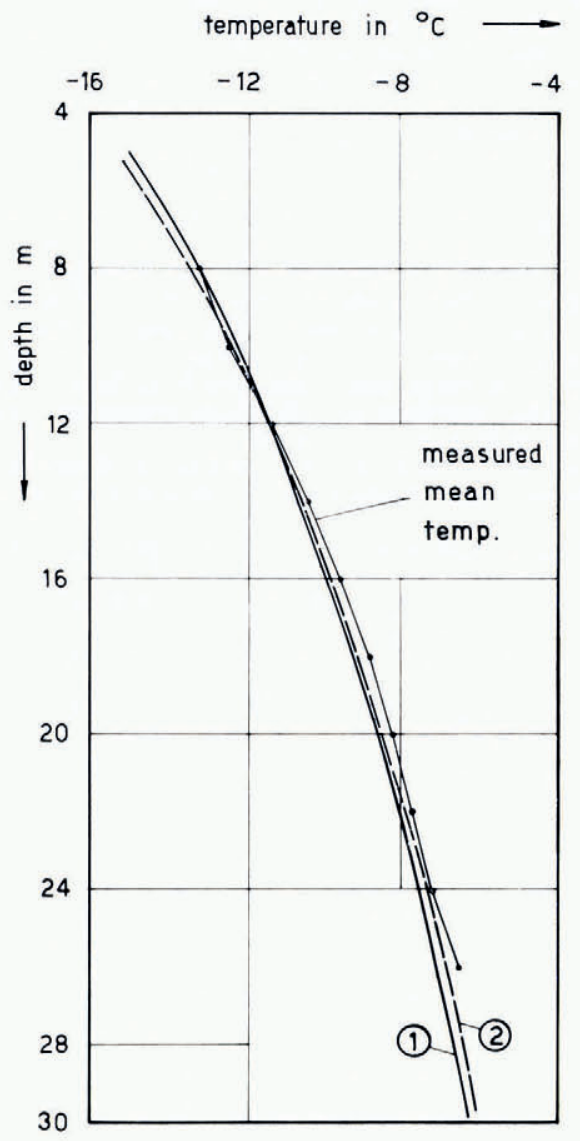

Fig. 11. Comparison of measured and calculated (1) and (2) mean temperatures $8 \mathrm{~m}$ to $30 \mathrm{~m}$ depth below ice surface at Lower Ice $205 \mathrm{~m}$.

\section{REFERENCES}

Adams, W. P. 1966. Glaciology, No. I. Ablation and run-off on the White Glacier, Axel Heiberg Island, Canadian Arctic Archipelago. Axel Heiberg Research Reports, McGill University, Montreal. Facobsen-McGill Arctic Research Expedition 1959-1962.

Benson, C. S. 1962. Stratigraphic studies in the snow and firn of the Greenland ice sheet. U.S. Snow, Ice and Permafrost Research Establishment. Research Report 70.

Iken, A. 1974. Glaciology, No. 5. Velocity fluctuations of an Arctic valley glacier, a study of the White Glacier, Axel Heiberg Island, Canadian Arctic Archipelago. Axel Heiberg Island Research Reports, McGill University, Montreal.

Khmelevskoy, I. F. 1968. Temperaturnyy rezhim verkhnikh sloyev lednikovogo pokrova [Temperature regime of the upper layers of the ice sheet]. Resul'taty Issledovaniy po Programme Mezhdunarodnogo Geofizicheskogo Goda. IX Razdel Programmy $M G G$, No. 18, p. I 53-72.

Krenke, A. N. I963. Discussion on paper by M. G. Grosswald and A. N. Krenke. Recent changes and massbalance of the glaciers on Franz Josef Land. Bulletin de l'Association Internationale d'Hydrologie Scientifique, Vol. 8, No. 2, p. 94-95.

Maag, H. U. 1969. Ice dammed lakes and marginal glacial drainage on Axel Heiberg Island, Canadian Arctic Archipelago. Axel Heiberg Island Research Reports, McGill University, Montreal. Jacobsen-McGill Arctic Research Expedition 1959-1962.

Miller, M. M. [1956.] Glaciothermal studies on the Taku Glacier, southeastern Alaska. Union Géodésique et Géophysique Internationale. Association Internationale d'Hydrologie Scientifique. Assemblée générale de Rome, 1954, Tom. 4, p. 309-27. 
Müller, F. 196r. Englacial temperature measurements. (In Müller, F., and others. Jacobsen-McGill Arctic Research Expedition to Axel Heiberg Island, Queen Elizabeth Islands. Preliminary report of 1959-196o, by F. Müller and members of the expedition. Edited by B. S. Müller. Montreal, McGill University, p. 87-99.)

Müller, F. 1962. Zonation in the accumulation area of the glaciers of Axel Heiberg Island, N.W.T., Canada. Journal of Glaciology, Vol. 4, No. 33, p. 302-1 1 .

Müller, F. Ig63[a]. Englacial temperature measurements. (In Axel Heiberg Island Research Reports, McGill University, Montreal. [Jacobsen-McGill Arctic Research Expedition 1959-1962.] Preliminary report 1961-1962, p. $8 \mathrm{r}-8 \mathrm{~g}$.)

Müller, F. I963[b]. Englacial temperature measurements on Axel Heiberg Island, Canadian Arctic Archipelago. Union Géodésique et Géophysique Internationale. Association Internationale d'Hydrologie Scientifique. Assemblée générale de Berkeley, 19-3-31-8 1963. Commission des Neiges et des Glaces, p. 168-80.

Müller, F., and Iken, A. 1973. Velocity fluctuations and water regime of Arctic valley glaciers. Union Géodésique et Géophysique Internationale. Association Internationale d'Hydrologie Scientifique. Commission de Neiges et Glaces. Symposium on the Hydrology of Glaciers, Cambridge, 7-13 September 1969 , p. ${ }^{16} 5_{-82}$.

Orvig, S., and Mason, R. W. 1963 . Ice temperatures and heat flux, McCall Glacier, Alaska. Union Géodésique et Géophysique Internationale. Association Internationale d'Hydrologie Scientifique. Assemblée générale de Berkeley, 19-831-8 1963. Commission des Neiges et des Glaces, p. I81-88.

Redpath, B. B. I965. Geophysics, No. 1. Seismic investigations of glaciers on Axel Heiberg Island, Canadian Arctic Archipelago. Axel Heiberg Island Research Reports, McGill University, Montreal. Jacobsen-McGill Arctic Research Expedition 1959-1962.

Schytt, V. I955. Glaciological investigations in the Thule Ramp area. U.S. Snow, Ice and Permafrost Research Establishment. Report 28.

Schytt, V. 1964. Scientific results of the Swedish glaciological expedition to Nordaustlandet, Spitsbergen, 1957 and 1958. Geografiska Annaler, Vol. 46, No. 3, p. 243-81.

Schytt, V. 1969. Some comments on glacier surges in eastern Svalbard. Canadian Journal of Earth Sciences, Vol. 6, No. 4 , Pt. 2, p. $867-73$.

Trabant, D., and others. I975. Thermal regime of McCall Glacier, Brooks Range, northern Alaska, by D. Trabant, W. D. Harrison and C. Benson. (In Weller, G., and Bowling, S. A., ed. Climate of the Arctic. Fairbanks, Geophysical Institute, University of Alaska, p. 347-49.)

\section{DISGUSSION}

M. M. Miller: The seemingly anomalous thermal profile in the accumulation zone which you explain by percolation perhaps has another explanation. For example, in Alaskan glaciers we have found a possibly comparable situation-i.e. colder ice near the equilibrium line (névé-line in these more temperate cases), at least in early winter profiles. We have considered this to relate to heavy snowfall in the autumn, at which time accumulation is maximum at higher elevation, yet often with bare ice remaining exposed below the névé-line. This new snow-pack (with low diffusivity) insulates the higher reaches against penetration of the early winter cold wave. As further snowfall occurs, this ultimately lowers the point of origin of the annual temperature wave. In contrast at the névé-line, the much larger diffusivity of bare ice and the presence of exposed crevasses permit deeper penetration of the early season cold. In other words, the blanketing snow at higher levels tends to increase the amplitude and lag effects of the cold wave and effectively impedes its penetration. I wonder whether this might be a causal factor in the development of your out-of-phase thermal profiles, or at least a supplement to the percolation mechanism which you describe?

F. MüLLER: The insulating effect of the early winter snow cover may also play a considerable role in the near-surface temperature regime of the White Glacier; it would supplement and strengthen the percolation effect. However, it seems to be of lesser importance on the White Glacier for the following reasons: (I) The early winter snow cover seldom amounts to more than one metre and is often less at Beaver Camp (accumulation area); and (2) The early spring temperature profiles for the first five or six metres below the surface show temperatures which are little different from those near the equilibrium line; the drastic warming in the accumulation area occurs during the warm part of the summer, after the $0^{\circ} \mathrm{C}$ line has reached this altitude.

W. D. HARrison: How did you know that the lower part of the glacier is sliding? 
MülLER: Müller and Iken (I973) have shown that there are large variations in the velocity during the summer that can only be explained by sliding.

HARRISON : Is there a finite layer of isothermal ice at the base?

Müller: We do not know yet because we do not know whether any of our deep holes have penetrated to bedrock.

R. LeB. Hooke: To what do you attribute the zero lapse rate?

MüLlER: The mean annual zero lapse rate results from the strong inversion during the winter and spring months, as revealed by the radio-sonde data of Eureka and Isachsen and the automatic weather station data from the White Glacier area. 